\title{
Interference of Sand Sagebrush Canopy with Needleandthread
}

\author{
JOSEPH H. DAVIS, III AND CHARLES D. BONHAM
}

\begin{abstract}
The influence of sand sagebrush (Artemisia filifolia) on the biomass of several components of needleandthread (Stipa comata) was studied on grazed and ungrazed sites in eastern Colorado. The components examined were seeds, stems-leaves combined, crowns, and total plant biomass. A significant grazing $x$ association interaction was observed in terms of seed biomass and stem-leaf combined biomass. Sagebrush afforded protection for needleandthread from grazing, which outweighed the effects of interference on grazed sites. In contrast, on the ungrazed site needleandthread biomass was greater in the open than underneath the sage. These results imply that a comparison of yield in pure and mixed stands on grazed sites are not valid for measuring interference effects between shrubs and grasses. The advantage of measuring several plant components in competition studies was also discussed.
\end{abstract}

It has been recognized since the early 1900's that overgrazing has given a competitive advantage to less desirable forage plants and has resulted in poor range conditions (Wooton 1908). Fluctuations in vegetation responses resulting from range management manipulations are best understood only when interference relationships can be accurately described (Hanson et al. 1931; Stoddart et al. 1955).

Effects of interference between sagebrush (Artemisia spp.) and grasses have been previously documented (Robertson and Pearse 1945; Blaisdell 1949; West and Tueller 1972; Rittenhouse and Sneva 1976). Often these effects were studied in the greenhouse or in pots placed in the field (Robertson 1972 ; Bailey and Gupta 1973; Rennie 1974) and such experiments have been criticized because the extrapolation of results from artifical environments to natural conditions was of questionable value (Harper 1961; Palmblad 1968a,b; Risser 1969).

Many experiments of plant interference, even those performed under natural field conditions, had parameters that consisted solely of collective aboveground and belowground components (Bailey and Gupta 1973; Rennie 1974; Rittenhouse and Sneva 1976). Harper (1961) noted that as density increased, the allocation of assimilatory products to the various organs of the plant may change. This indicated that a more critical examination of these component organs would be in order. Some recent research has dealt with components such as leaf, stem. seed, crown and root biomass (Grafius 1972; Rennie 1974).

Many studies involving interference between shrubs and forage grasses have tended to emphasize shrub control treatments or effects on reseeding practices (Robertson 1969;

The atuthors are graduate student and professor. Range Science Department. Colorado State Liniversity. Fort Collins 80523

This research was supported by Colorado State University Experinent Station Project 190. Experiment Station Scientifï Series Number 2434

Manuscript received June 7.1978
Schlatterer and Tisdale 1969; Eckert et al. 1972; Scifres and Polk 1974). Perhaps because of limited practical applications, studies strictly concerned with the ecological aspect of interference between grasses and shrubs are few in number. Ecological studies involving forage species in association with sand sagebrush (Artemisia filifolia Torr.) are virtually nonexistent.

The purpose of the present study was to determine the effects of interference and grazing on total aboveground biomass of needleandthread (Stipa comata Trin. \& Rupr.), and furthermore how individual aboveground compartments of this grass were affected by interference from sand sagebrush and grazing.

\section{Site Description}

The Eastern Colorado Agriculture Research Center is located in the Central Great Plains about $27 \mathrm{~km}$ north of Akron in the sandhills of northeastern Colorado. The elevation averages $1,300 \mathrm{~m}$ and the topography varies from nearly level to slightly rolling dunes (Sims et al. 1976). The study site has a continental climate with hot, dry summers, mild, dry autumns, cold winters, and moist, cool springs (Trewartha 1968; Sims et al. 1976). Average annual precipitation ranges between 33 and $43 \mathrm{~cm}$, of which 75 to $80 \%$ occurs during the growing season (USDA 1975). There are about 140 frost-free days starting in mid May and ending in early October (Dahl 1963). The area frequently experiences high intensity summer storms with hot, dry periods between storms being common.

This study was conducted on Blakeland loamy sand which has a deep sandy profile. Moisture penetration is rapid and deep, which prevents great losses as a result of evaporation. Rapid drying of the surface soil contributes to reduction of evaporation at lower depths and moisture is given up rapidly to plant roots (USDA 1975). The drainage pattern is undefined in the dune area, and the soils are relatively low in organic matter.

The study site was located in an area moderately grazed since 1970 . A 0.2-hectar exclosure was used as an ungrazed site, while the area outside of the exclosure served as the grazed site. The exclosure had not been grazed since 1953 .

Sims et al. (1976) described the native vegetation of this area as heterogeneous, consisting of short, mid, and tall grasses, as well as mixtures of cool- and warm-season species. The major species include blue grama [Bouteloua gracilis (H.B.K.) Steud.], prairie sandreed [Calamovilfa longifolia (Hook.) Scribn.], needleandthread, sand bluestem (Andropogon hallii Hook.), western wheatgrass (Agropyron smithii Rydb.), and sand dropseed [Sporobolus cryptandrus (Torr.) Gray]. Sand sagebrush occurs as the principal shrub and sun sedge (Carex heliophila Mack.) is the principal dryland sedge. Common forbs in the area include perennial ragweed (Ambrosia coronopifolia Torr. and Gray), cudweed sage (Artemisia ludoviciana Nutt.), wild alfalfa (Psoralea tenuiflora Pursh), and bush morning glory (Ipomoeae leptophylla Torr.).

\section{Methods}

Twenty-four cages, approximately $1 \mathrm{~m}^{2}$ in area, were used as mini- 
A greenhouse study of the effects of sand sagebrush interference on needleandthread may indicate that this shrub suppresses grass yield, as was indicated in the exclosure of this study. However, to extrapolate such results to a grazed condition would be a mistake. For under grazing pressure, the protective nature of the shrub caused yields of needleandthread to be greater in the shrub understory than in the open pasture. Therefore, since effects of grazing far outweigh those of interference, it becomes a formidable task to quantify competition based on comparison of grazed pure and mixed stands. Field experiments measuring effects of interference between shrubs and grasses should, therefore, be performed on ungrazed sites which preferably have been protected for several years.

In studies of shrub and grass interference effects, in exclosures where grazing is not confounded with association, examination of plant yield is a valid comparison. Results from this study suggested that plant yield or biomass might not be the best parameter to measure effects of interference of successional changes related to these effects, especially in areas with a history of grazing. Plant yield in the presence of a shrub does not appear to be adversely affected because of confounding with grazing. Over a long-term period, however, grass yields have been shown to decrease in the presence of shrubs (Rittenhouse and Sneva 1976). The grazing $\times$ association interaction of this study indicated that the protective nature of the shrub on grazed areas will not allow valid comparisons to be made between yields of plants associated with a shrub and yields of plants in the open to determine effects of the shrub interference. Some characteristic besides yield would be beneficial in detecting this decrease on grazed sites over a short term. Perhaps gross energy, cover, or crown diameters would provide more accurate estimates of the effects of the shrub on grasses.

This study indicated that measurements of several plant components rather than total biomass alone were more sensitive in detecting changes which resulted from the combined effects of grazing and association. Significant grazing $\times$ association interaction was detected using biomass of seeds and stems and leaves, whereas total plant biomass did not indicate a significant interaction.

As optimum production of forage plants becomes more important in an increasingly populated world, knowledge of the relationship between valuable and undesirable plants in association with each other becomes a necessity. This work has examined the effect of sand sagebrush on the yield of several components of needleandthread. It has also shown that effects of association can be confounded by grazing pressure, and measures of yield alone in grazed areas may lead to erroneous conclusions regarding the effect of the shrub. In addition, this study has shown that measures of the biomass of multiple components of a grass are more sensitive in detecting the combined effects of plant interference and grazing than are measurements of total aboveground biomass alone.

\section{Literature Cited}

Bailey, Arthur W., and R.K. Gupta. 1973. Grass-woody plant relationships. Can. J. Plant Sci. 53:671-676.

Blaisdell, J.P. 1949. Competition between sagebrush seedlings and seeded grasses. Ecology 30:512-519.

Dahl, B.E. 1963. Soil moisture as a predictive index to forage yield for the sandhills range type. J. Range Manage. 16:128-132.

Eckert, R.E., A. Bruner, and G.J. Klomp. 1972. Response of understory species following herbicidal control of low sagebrush. J. Range Manage. 25:280-285.

Grafius, J.E. 1972. Competition for environmental resources by component characters. Crop Sci. 12:364-367.

Hanson, H.C., L.D. Love, and M.S. Morris. 1931. Effects of different systems of grazing by cattle upon a western wheatgrass type of range. Colorado Exp. Sta. Bull. No. 377. Colorado State Univ., Fort Collins. 82 p.

Harper, J.L. 1961. Approaches to the study of plant competition. Symp. Soc. Exp. Biol. 15:1-39.

Palmblad, I.G. 1968a. Competition in experimental populations of weeds with emphasis on the regulation of population size. Ecology 49:26-35.

Palmblad, I.G. 1968b. Comparative response of closely related species to reduced competition. I. Senecio sylvaticus and S. viscocus. Can. J. Bot. 46:225-228.

Rennie, J.L. 1974. Some effects of competition and density of plants on dry weight produced. Ann. Bot. 38:1003-1017.

Risser, P.G. 1969. Competitive relationships among herbaceous grassland plants. Bot. Rev. 35:251-284.

Rittenhouse, L.R., and F.A. Sneva. 1976. Expressing the competitive relationship between Wyoming big sagebrush and crested wheatgrass. J. Range Manage. 29:326-327.

Robertson, J.H. 1969. Yield of crested wheatgrass following release from sagebrush competition by 2,4-D. J. Range Manage. 22:287-288.

Robertson, J.H. 1972. Competition between big sagebrush and crested wheatgrass. J. Range Manage. 25:156-157.

Robertson, J.H., and K.C. Pearse. 1945. Artificial reseeding and the closed community. Northwest Sci. 19:58-66.

Schlatterer, E.F., and E.W. Tisdale. 1969. Effects of litter of Artemisia, Chrysothamnus and Tortula on germination and growth of three perennial grasses. Ecology 50:868-873.

Scifres, C.J., and D.B. Polk. 1974. Vegetation response following spraying a light infestation of honey mesquite. J. Range Manage. 27:462-465.

Sims, P.L., B.E. Dahl, and A.H. Denham. 1976. Vegetation and livestock response at three grazing intensities on sandhill rangeland in eastern Colorado. Colorado State Univ. Exp. Sta., Tech. Bull. No. 130. 48 p.

Stoddart, L.A., and A.D. Smith. 1955. Range Management. McGraw-Hill Book Co., New York. 433 p.

Trewartha, G.T. 1968. An Introduction to Climate. McGraw-Hill Book Co., New York. 408 p.

U.S. Dep. Agr., U.S. Soil Conservation Service. 1975. National Range Handbook Range Site No. 24. 3 p.

West, N.E., and P.T. Tueller. 1972. Special approaches to studies of competition and succession in shrub communities, p. 172-181. In: C.M. McKell et. al. (eds.) Wildland Shrubs-Their Biology and Utilization. U.S. Dep. Agr. Forest Serv. Tech. Rep. INT-1.

Wooton, E.O. 1908. The Range Problem in New Mexico. New Mex. Agr. Exp. Sta. Bull. No. 66. 46 p. 